\title{
Experiencing Pedagogical Practices with Digital Resources in The Teacher Training of English Teachers
}

\author{
Ângela Musskopf, Instituto Ivoti, e-mail: angela.musskopf@institutoivoti.com.br \\ Débora Nice Ferrari Barbosa, Universidade Feevale, e-mail: deboranice@ feevale.br \\ Patrícia B. Scherer Bassani, Universidade Feevale, e-mail: patriciab@feevale.br
}

\begin{abstract}
This research deals with the inclusion of digital educational resources in an English teacher-training course and the possible benefit from the use of this in the improvement of the students' proficiency level. For that, the researchers understood that it was necessary to study theories of second language learning and look for common principles between such theories and information and communication technologies (ICT). The use of the cartographic method to develop the research resulted in three categories of analyses: (a) the relation between SLL theories and ICT; $(b)$ the relation between the students and ICT; and (c) the students' proficiency level in English. The research generates products which can be used in the processes of teaching and learning in Basic Education, such as papers and a presentation.
\end{abstract}

Keywords: SLL theories. ICT. Teacher training. English proficiency level.

\section{Experimentando práticas pedagógicas com recursos digitais na formação de professores de Inglês}

Resumo: Esta pesquisa trata da inserção de recursos educacionais digitais em um curso de Letras - Português e Inglês, Licenciatura e o possível benefício destes no desenvolvimento do aprimoramento linguístico dos alunos. Para isso, houve a necessidade de verificar se os recursos digitais iam ao encontro dos princípios preconizados pelas teorias de aprendizagem de segunda língua (L2). A utilização do método cartográfico resultou em três categorias de análise: (a) a relação entre teorias de aprendizagem de L2 e as tecnologias da informação e comunicação (TIC), (b) a relação entre os alunos e a TIC e (c) o nível de proficiência linguístico dos alunos. A pesquisa gerou produtos que podem ser usados em processos de ensino e de aprendizagem na Educação Básica, como artigos e uma apresentação.

Palavras-chave: Teorias de aquisição de L2. TIC. Formação de professores. Nível de proficiência em inglês.

\section{Introduction}

Today's world and its overwhelming connectivity and the consequent possibilities of use in the educational area imposes some deep reflection related to pedagogical practices in classrooms, especially in teacher training courses. Hybridism, multi-literacy, information and communication technology must not be ignored by education, on the contrary, they must assist it in the broadest possible form. So, this study is based on the question that if undergraduates experience ICTs while they are at university, they are more likely to incorporate them into their practices as teachers. At 
the same time, they might observe the benefits of digital resources by improving their own level of English.

For us, information and communication technologies (ICTs) is a term that encompasses digital resources, generally speaking, online and offline. Owing to the fact that this research deals with the issue of English as a second language and the use of ICTs to promote better learning, second language learning theories help to understand the processes and approaches involved. Authors such as Ellis (2000), Mitchell and Myles (2004) and Lightbown and Spada (2013) have their views and believes mentioned, and researchers such as Chapelle (2016) and Leffa and Freire (2013) also discuss the reasons to use ICTs in language teaching.

There are evidences showing that technology is not as much used inside classrooms as one would be expected it to be (MAPELLI, 2018, PONTO BR, 2017), even though Government documents (such as the BNCC) mention and motivate people involved in education to explore it. Therefore, the core issue is: how to train future teachers to be prepared to use ICTs in their professional life as teachers? To reach an answer to this question, this work proposes pedagogical practices using ICT digital resources in a Higher Education institution with a group of students studying to be teachers of English as a Second Language (ESL/EFL).

The practices reported in this paper are also shown in three individual papers, which two of them are already published (MUSSKOPF; BARBOSA; BASSANI, 2018) and (MUSSKOPF; BARBOSA, 2018a). They describe the pedagogical practices developed related to the general and specific concerns of the research during each semester. These practices were developed from August 2017 to December 2018, that is three semesters during which students were enrolled in subjects named English II, English III and English IV, respectively. The focus in these subjects was to improve the students' proficiency level so that they would be able to reach an intermediate level defined as B1 according to the Common European Framework of Reference (CEFR, 2018).

This paper is organized this way: first, we got the introduction. Item 2 illustrates the scenario of teacher training courses around the city where the research was conducted. Then, item 3 explains the methodology and the practices. Item 4 shows the analysis and it's results, then we have the conclusion.

\section{Teacher training scenario}

During the research, we concluded that students who have been entering our institution seem to not have known about the available digital resources, hence ignoring how to use them. In the first semester, when asked about which ones they are used to, they answered the common ones: word and power point. This apparent lack of knowledge about digital resources applied to education is shown in an updated study, a survey on the Use of Information and Communication Technologies in Brazilian Schools (PONTO BR, 2017, p. 260) from 2016 showed that 54\% of the teachers answered they did not have any specific subject on how to use computers and the Internet in activities with students during their Tertiary Education. This means that teachers in Brazil still start their professional lives without having tried out ICTs during their training. 
It could be implied that because of the widespread use of technology in many sectors of society, such as banking, marketing, business, ICTs would already be part of the curriculum in teacher training courses and, consequently, in their pedagogical practices. However, corroborating with the view of the survey mentioned above, Nina Mapelli's study points out that the use of technology in classrooms is not quite a reality. Mapelli (2018) found that students who were still undergraduates and performing their teaching practice were not using technology resources in classrooms even though they had contact with them previously at university.

Furthermore, according to Musskopf and Barbosa (2018), fresh teachers still reach schools without having knowledge about digital resources, not even the ones designed for educational contexts, a situation that is also acknowledged by Mappelli. Therefore, a point to be discussed is why undergraduates use digital resources so little and not in an innovative way if during their training they had some contact with ICTs? In our opinion, a different approach should be considered: technology should not be taught as an isolated subject, but practices with digital resources must be implemented in all disciplines of the curriculum as an organic topic, part of all training and usable in various contexts.

Paiva (2013) believes that the more teachers incorporate ICTs in their practices inside classrooms, more possibilities there will be to spread innovations and positively influence the future teachers. Experiences with digital resources must be experienced in a systematic way by the future teachers and not as an isolated component. It is through their involvement while at university that English teachers will be prepared to think about innovative pedagogical practices applying ICTs in their professional setting. Including one or two subjects in the curriculum might not be enough.

Encouraging recently graduated teachers to deal with available digital educational resources, especially the ones that are suitable to second language acquisition theories, this may promote not only the familiarity with ICTs but also the linguistic improvement of the students during their undergraduate course.

\section{Methodology and practices}

In this study, the cartography method was used to develop the research since subjectivity is involved in the actions developed. According to Passos, Kastrup and Escóssia (2009), "Cartography must be understood as a method according to which all research is driven to a clinical-policy direction and all clinical practice is, in its turn, an intervention generating knowledge". (PASSOS; KASTRUP; ESCÓSSIA, 2009, p. 2526).

In this study, the pedagogical practices were developed with subjects enrolled in an undergraduate course located in the region of Vale do Rio dos Sinos, RS. During the first semester of 2017, in a class called English 1, aimed at improving the students' knowledge of the English Language, through activities and discussions in classes, the teacher noticed that the students did not know about digital educational resources neither in general nor related to language learning. Therefore, the teacher decided to explore experiences involving ICTs not only to present them to students but also to enhance their proficiency. The progress expected could be described by the CEFR: English II corresponds to A2, English III to B1 and English IV, to B2.1. 
Considering this method, by having a clear starting point (which was the inclusion of ICTs in a teachers' training course so that they would experience them) and a reaching point (to be able to evaluate their usage benefits), previously the path from $\mathrm{A}$ to B could be neither determined nor closed. Data started to be collected in August 2017 and finished in December 2018, which configures an extended period of time during which the path from A to B would be shaped by the group and the researcher. The practices resulted in different movements along the way, which could be compared to commuting from a house to the workplace: there are probably many routes to take to get there.

It was clear that many forces would be surrounding the research territory which would be inhabited by the researcher and the students provoking not only a change in the reality around them, in knowledge, but also a change in themselves, as learners during the process. As odd as it might seem, objectivism and subjectivism would coexist, complementing each other. The practices developed would search for data at the same time they would consider the adaptation and reorganization of the territory while following the processes. At times the subjects involved in the process would analyse aspects from inside, although there would be times that they would proceed as they were hovering and observing from above.

When processes are followed, there is a necessity of registering them to assure that details would not be lost in the long run. This may cause a change in describing the experiences, a different shape so that the results would not be lost along the way. While finishing one pedagogical practice, it was necessary to reflect about this part, to evaluate whether it indicated a swerve to the right, or to the left, or continued straight ahead. Hence, the proposal of the final product was to put together three papers which were conducted by a thread which passes throughout all practices and though described separately, are part of only one complex, structured research.

Due to all these features, the cartographic method seemed to be suitable to be applied in the pedagogical practices involved in this research. In the first practice, the teacher created a page on Edmodo and invited students to join it so that a virtual space was available for support, interaction, and sharing. This practice was developed from August to December 2017, in the English 2 subject, when the teacher realised students were working for the first time with Google Classroom and they were amazed by its possibilities. As a result of a social education network which could be used by the students in their schools was presented and used. The decision was based on the ranking of the Centre of Learning \& Performance Technologies which places Edmodo amongst the Top 100 Tools for Education in 2017. The goal was to promote a network where students would be able to shares ideas, suggestions, interact and have a place where they could find support. Since then, students have been interacting and posting materials they consider interesting and need to be shared.

This page was built by the subjects involved and was used for many purposes, such as helping with some linguistic difficulties, share some videos with activities for students, papers which were discussed with the group, they also posted their opinions and interacted with their classmates' comments. At the end of the period, there were sixteen different posts. When this practice started, the objective was to have a place to share and interact but there was no idea on how students would react to this proposal, which in the end, seemed very positive, as they are keeping it updated for the third semester. Students speeches, reactions, and participation was based on the analyses. 
The second practice came up when, during a writing task, students expressed their concerns about the writings tasks which are part of their grades. To meet this difficulty, the teacher planned to focus on this ability during the following semester. These analyses were based on one of the resources used, which generates data compiled in graphics.

This practice was developed from February to July 2018, in the English 3 subject, because students were struggling with the writing tasks of the course. In their own first language students only have the opportunity to write formal essays at university and this cannot be considered a habit. Due to this, this paper proposes pedagogical practices with four digital educational resources to promote moments to improve this specific skill. The means were chosen due to the Institution's connection to Cambridge, which runs the English Profile. Although Future Learn hosts many MOOCs (Massive Open Online Courses) from Cambridge, at the time of the practice there was no writing course being offered by this university, therefore the group used a course offered by the University of Reading in the United Kingdom.

The third practice evolved from the previous ones, joining the social educational network to the writing resources. But with the difference that the platform was subscribed to by the teacher and provided more features for herself and the students. The network was used to share content that the students produced about a specific topic they elected as being difficult rearding writing. These posts were accessed by all students to enlarge their personal knowledge and also while they were performing their writing task directly on the platform. The main difference is that the premium version offers a feedback box where the teacher can write individual comments to each student and a progress chart so that the teacher can follow their progress.

\section{Reflecting on the whole process}

The cartographic method is based on following processes which means that observation and reflection go together with theory and practice while the research is being developed. Even so, at the end of the 18 months during which the pedagogical practices were developed, it seems reasonable to look back at the entire process.

Keeping in mind that the main objective was to develop pedagogical practices with digital educational resources with students preparing themselves to become English teachers and to verify their influence in the linguistic knowledge of the students, taking into consideration the students' reality before the first practice (they mentioned unfamiliarity with much of the resources used) and listening to them explaining to the English teachers after the last practice, we believe the experience was mostly positive.

It was possible to organize three categories to be analysed: (a) the relation between second language learning theories and the digital resources used, (b) the familiarity of resources and practices by the students, and (c) the improvement in their English proficiency level.

4.1 Category a: Relation between second language learning theories and ICT'S

During all pedagogical practices proposed, students had to interact with each other and the teacher, receiving feedback from their peers and the teacher, using language for a communication purpose in a social context as Vygotsky (1991), Primo (2007) Lightbown and Spada (2013), and Mitchell and Myles (2004) state as being 
necessary to support a meaningful learning process. Tasks performed always had an objective and the resources were a mechanism to mediate communication between all the agents involved, which Leffa and Freire (2013) declare to be one possibility of learning, inside and outside the classroom, so that the geographic space was not a barrier. According to Ellis (2000), language acquisition can take more time for some students so the fact that the practices were developed during three semesters allowed students to experience the resources more than once, giving them time to become familiar with them, making their brain store information from the short-term memory to the long-term memory (MITCHELL; MYLES, 2004).

The data collected showed that theories of second language acquisition mentioned supporting the use of digital resources in the curriculum for both language and cognitive development. Yet, more than once, the undergraduates mentioned they were using some tools in other classes and accessed resources such as the Thesaurus to help in the tasks they had as homework.

4.2 Category b: Students and digital resources

Despite not exploring all features of the digital resources used, students became familiar with them and this triggered their autonomy in developing knowledge, according to Moreira (1999), leading them to explore more possibilities in the resources presented and even looking for new ones

The feedback of the Write and Improve also developed student's autonomy by making them proofread and offering some guidance on possible mistakes that could be solved by themselves. Moreover, for this moment the undergraduates also chose a digital resource one of them discovered while surfing the web. These facts promoted the learners' autonomy, an important aspect which was also emphasised by authors such as Ellis (2000) and Moreira (1999).

In the third practice, Edmodo was used to share content developed by the students about a topic of their own choice, each one related to an aspect of writing they considered to be difficult. They used this digital resource very comfortably and had no problems in posting their tasks. Furthermore, students felt confident while using the Write and Improve platform to perform their final writing task. This pedagogical practice in particular allowed students to interact, to notice their production becoming aware of language features, to process their development of syntax and morphology features and practice, engaging in what is meaningful and focused on what is essential for the tasks, as stated by Lightbown and Spada (2013).

\subsection{Category c: Proficiency level of English}

With the possibility of editing posts provided by Edmodo, students were able to improve their language skills by noticing and correcting their mistakes. This specific feature was considered very interesting for both language improvement and safe environment exposure due to the fact that they knew they would not be judged or criticised as it frequently happens on social networks like Facebook. For example, the essay activities focused on task-essential forms, in which students engaged in discussions, planning, organizing and summarizing ideas, choosing words to express their opinions and experiencing how to upgrade them resulting in the different levels of proficiency shown by the resources and noticed by the students themselves. 
Also, students mentioned they noticed their improvement, which was shown by the data collected in the Text Inspector, for example, in which the level of vocabulary increased. Improvement was also detected in the progress graphics generated on the Write and Improve platform. Another writing task with substantial progress on the proficiency level was the one proposed by the MOOC in which students received guidance on task-essential forms. These instructions provided by the MOOC proved to be useful and effective.

The indications of improvement described in the results of the papers provides evidence to endorse the implementation of more pedagogical practices with ICTs to develop meaningful content related to second language acquisition, improving the students' proficiency level.

The pedagogical practices described in this research show a different point of view from the role of technology in teacher training courses in the region. As explained in chapter 1 , in most courses, technology is treated as a separated component, while in this study it was considered in an organic way, integrated to English disciplines in which language and technology were used concomitantly.

To promote innovative practices through the digital resources so that students feel confident in using them in other contexts, hopefully in their own practice as teachers, was a challenge. First, I had to look for resources that were interesting, friendly and useful in education while at the same time helping students to improve their linguistic level. The fact that one student searched a new resource on her own shows she became confident enough to take risks and unveil new possibilities.

Despite all the benefits and positive results, some fragilities can also be pointed out. It was worrisome starting a journey knowing where to start and finish but not being able to imagine the exact path between them. Once you take the first step, you may have to change direction to the left, to the right, step back and reconsider some things, instead of moving straight ahead, you may have to swerve. The researcher has to be flexible and to adapt while the processes are going on, and during them learning and transformation of the author happens following the "effects of multiple practices of the research which allows access to where everything merges: subjects, objects, field, investigator, participants, issues, texts, shortcuts and worlds" (PASSOS; KASTRUP; TEDESCO, 2016, p. 49).

After walking for some time, developing the first practices, I felt more comfortable in making the decisions lead by the study field itself and the students promptly engaged in the proposals. This showed that the road taken was being wellbuilt and the procedures were being validated by the subjects involved.

Observation is, in my opinion, the key to success. In the beginning it was a little difficult to observe, but it was utterly necessary, and the cartographer must be very attentive; there was no control on how the practices were going to develop, what the sequence would be, because the movement during the process would show the way and this could not be previously stablished. Even though this is understandable, related to academic research it could create an obstacle if the people involved in the process are not flexible to where the flow would take them. In the case of this study, the participants were very open to the practices and this is probably connected to the confidence boosted among the group. In this context the word confidence does not mean the feeling that you can trust, but 'the constitution of a plan to a shared experience, in which the 
singularities of the meetings present in the field enables to multiply the possibilities of connections among the subjects and the worlds" (PASSOS; KASTRUP; TEDESCO, 2016, p. 68).

\section{Conclusions}

ICTs have become ubiquitous and are of great importance in education. The aim of this study was to promote pedagogical practices with digital education resources with undergraduate students studying to become English teachers increasing their experience with digital resources while contributing to their linguistic development.

The main objective was to develop pedagogical practices with digital educational resources with students preparing to become English teachers and to verify their influence in the linguistic knowledge of the students. During a period of 18 months a variety of resources, some directly connected to English language development and others not, were used by the future teachers. They discovered new possibilities, which helped them to improve their English knowledge, they were user-friendly and allowed to gather the group's opinion in a few minutes, such as Mentimeter and the word cloud activity, instead of asking them to raise their hands to be counted.

Related to the specific objectives, literature review and the analyses of the curriculum of teacher training courses indicate that although documents that rule the education system in Brazil mention the importance using technology with students, initiatives are still very poor in the region. The theories of second language acquisition support the use of digital resources in the curriculum. Data collected indicated an improvement in the proficiency level of the students, which may indicate that digital resources collaborate in the students' linguistic awareness and learning. Important concepts such as interactivity, meaningfulness, linguistic awareness are met by the use of digital educational resources, which point out the benefits of their use in the current educational context.

This research involved innovate practices by combining practices using around ten digital resources the participants of the study did not know about before. More than once, students expressed they felt confident in using them in other contexts. This might suggest that these future teachers will hopefully develop pedagogical practices with their own students once they start teaching. After three semesters of pedagogical practices, students were presented to different possibilities of digital educational resources and noticed improvement in their linguistic level, also shown in the data of their writing production.

This study contributes to change the state-of-the-art context related to teacher training and the use of ICTs. The work demonstrated that the current isolated initiatives are not enough to promote what the legal documents that rule education in Brazil envision. Furthermore, all practices were developed in English disciplines, treating the use of digital resources as a part of them, in a systematic experience and expanding the scope instead of using them only in a specific subject.

Equally important, this study encourages teachers and students to take risks, unveiling new possibilities of digital pedagogical practices, spreading innovation and promoting creativity once the resources used may be explored for different purposes and in different ways. 
Moreover, this research also generated a presentation ${ }^{1}$ created by the students and used in the meeting with the English teachers of the subjects institution. This presentation was licenced under the Creative Commons licences to be shared and used as a basis for other products. This presentation will also be used in teacher training courses, contributing in spreading the possibilities of pedagogical practices for teachers involved in Fundamental and High School Education.

There are still suggestions that can be appointed, such as looking for ICTs that deal deeply with other skills, such as speaking, listening and reading, since in this study we focused on the writing skill because of the development of the processes. It would also be interesting to promote pedagogical activities with a group with a higher number of students, since this group was really small, having started with seven students and dropping down to 4 in the last semester.

In conclusion, it is believed that there are more advantages than drawbacks in including the digital world as an important issue in teacher training courses. Furthermore, the practices developed in this research may inspire more people involved in education to include technology in their teaching planning.

\section{Acknowledgements}

We thank the National Council for Scientific and Technological Development CNPq/Brazil (http://www.cnpq.br) for providing financial support for this study. Finally, we would like to thank Feevale University and Instituto Ivoti for embracing this research.

\section{References}

CHAPELLE, C. A . Second Language Learning Online. In: ANDREWS, R.; HAYTHORNTHWAITE, C. (Eds.). The Sage Handbook of E-learning Research. London: Sage Publishing, 2016. doi: 10.4135/9781848607859

CEFR (COUNCIL OF EUROPE). Common European framework of reference for languages: learning, teaching, assessment: companion volume with new descriptor. Feb. 2018. Available at: <https://rm.coe.int/cefr-companion-volume-with-newdescriptors-2018/1680787989>. Accessed in: 10 dec. 2018.

ELLIS, R. Second Language Acquisition. Oxford: OUP, 2000.

LEFFA, V. Redes sociais: ensinando línguas como antigamente. In: ARAÚJO, J.; LEFFA V. (Org.). Redes sociais e o ensino de línguas: o que temos a aprender? São Paulo: Parábola Editorial, 2016. p.137-153.

LIGHTBOWN, P.; SPADA, N. How languages are learned. Oxford: Oxford University Press, 2013.

\footnotetext{
${ }^{1}$ Available at: https://view.genial.ly/5c199ca1cd013556bbc336e4/10 
MAPELli, N. Formação inicial docente e o uso de tecnologias digitais de informação e comunicação: levantamento de práticas educativas no ensino fundamental. 2018 Dissertação - Universidade Feevale, Novo Hamburgo, RS, 2018.

MITCHELL, R.; MYLES, F. Second Language Learning Theories. Banbury, UK: Hodder Arnold, 2004.

MOREIRA, M. A. Aprendizagem significativa. Brasília: UNB, 1999.

MUSSKOPF, A.; BARBOSA, D. N F. EDMODO: Experiencing a global education network. In: communications in computer and information science (print), v. 1, 2018. p. 131-141.

MUSSKOPF, Â.; BARBOSA, D. N. F.; BASSANI, P. B. S. ICTs and Second Language Learning. RENOTE, v. 16, n. 2, 2018. Available at: <https://seer.ufrgs.br/renote/article/view/89295/51534>. Accessed in: 07 dec. 2017.

PAIVA, V. L. M. O. A formação do professor para uso da tecnologia. In: SILVA, K. A. (Org.). A formação de professores de línguas: novos olhares. V. 2. Campinas, SP: Pontes Editores, 2013. p. 209-230.

PASSOS, E.; KASTRUP, V.; TEDESCO, S. Pistas do método cartográfico: pesquisaintervenção e produção de subjetividade. Porto Alegre: Sulina, 2009.

PASSOS, E.; KASTRUP, V.; TEDESCO, S. Pistas do método da cartografia: a experiência da pesquisa e o plano comum. V. 2. Porto Alegre: Sulina, 2016.

PONTO BR. Núcleo de Informação e Coordenação (Org.). Pesquisa sobre o uso das tecnologias de informação e comunicação nas escolas brasileiras: TIC Educação $2016=$ Survey on the use of information and Communication Technologies in Brazilian Schools: ICT in education 2016. São Paulo: Comitê Gestor da Internet no Brasil, 2017.

VYGOTSKY, L. S. A formação social da mente. 4. ed. São Paulo: Martins Fontes, 1991. 